\title{
Sediment selection by juvenile Arenicola marina
}

\author{
J. D. Hardege ${ }^{1, *}$, M. G. Bentley ${ }^{2}$, L. Snape ${ }^{2}$ \\ ${ }^{1}$ University of Wales, PABIO, Park Place, Cardiff CF1 3TL, Wales, UK \\ ${ }^{2}$ Gatty Marine Laboratory, University of St. Andrews, St. Andrews KY16 8LB, Scotland, UK
}

\begin{abstract}
Juveniles of the benthic polychaete Arenicola marina migrate until they recognise a substratum suitable for settlement. As in a number of marine invertebrates, inter- and intra-specific interactions are of importance in selecting a habitat, and specific chemical factors are involved. This study focuses on the sediment preferences of larvae and juveniles and includes an assessment of both the positive and negative chemical cues. The data confirm an attraction of juvenile conspecifics to each other during settlement in a gregarious type of positive response, whereas a negative response to sediments that have been populated by adult $A$. marina exists. Attraction and larval settlement were induced by a number of synthetic chemicals, including fatty acids, amino acids and tripeptides, and by Rhodomonas sp. and Nephtys hombergii populated sand. Aquatic fish food (Tetra-Marine, commercial trout diet) enriched sediment induces settlement at a similar range; this suggests that settlement can be induced non-specifically by water soluble compounds, which may indicate organically enriched and therefore potentially favourable sites for settlement. In A. marina, brominated aromatics (e.g. 3,5dibromo-4-hydroxybenzoic acid) inhibit settlement and function as negative cues in a similar way to those described for terebellid polychaetes. Negative cues may be more important than positive cues and their role in substratum choice by invertebrate lârvae hàs been underestimated.
\end{abstract}

KEY WORDS: Arenicola marina Annelid · Polychaete settlement cues · Fatty acids · Peptides

\section{INTRODUCTION}

At least 100000 benthic marine invertebrate species have pelagic larval stages for some period of their life history and this potentially allows dispersal over great distances (Thorson 1950). This dispersal leads ultimately to recruitment and subsequently the preferential choice of sites for settlement and metamorphosis. Environmental cues, especially those of a chemical nature, that induce settlement and metamorphosis of marine invertebrate larvae have been the subject of a number of recent investigations as reviewed by Chia \& Rice (1978) and more recently by Rodríguez et al. (1993).

Larval or juvenile settlement stimuli can be categorised into in a number of different forms. These include attractive positive chemical settlement inducers (with varying degrees of specificity) from different substrata and possible settlement sites (see Pawlik

•E-mail: sabjdh@cardiff.ac.uk
1992; see Rodríguez et al. 1993 for review), physical cues such as water current velocity and substratum contours (Pawlik et al. 1991) as well as photo- and geotaxis (Crisp \& Ritz 1973) and negative chemical signals that characterise sites unsuitable for settlement (Woodin 1991). A number of settlement inducing chemical cues have been postulated from observations of specific settlement on different natural substrata. The sources of these chemical cues can be classified into 3 main groups: (1) for many species the stimulus to settle is some component associated with the presence of conspecific individuals, e.g. the adult habitat, such as the gregarious settlement in some polychaete species (Jensen \& Morse 1984, Pawlik 1986), oysters (Crisp 1967) and ascidians (Svane et al. 1987); (2) inductive cues associated with the adult prey are described in opisthobranch molluscs feeding on bryozoans (Lambert \& Todd 1994) sponges (Chia \& Koss 1978) and barnacles (Todd 1979); in addition, crustose red algae that represent potential food sources induce settlement in abalone (Morse \& Morse 1984a), limpets 
(Stenneck 1982) and echinoplutei of sea urchins (Pearce \& Scheibling 1990, 1991); (3) microbial films of diatoms and bacteria are described as metamorphic inducers in a number of benthic invertebrates (Morse et al. 1984), such as oyster Crassostrea gigas larvae (Coon et al. 1985). Water soluble inducers such as L- $\beta$ 3,4-dihydroxyphenylalanine (L-DOPA) originate from bacterial films and induce both settlement and metamorphosis, whereas high levels of ammonia excreted by bacteria trigger the search activity in oyster larvae (Coon et al. 1990).

\section{Chemistry}

At the molecular level, a number of chemically different settlement cues have been described but only very few natural inducers have been isolated and chemically characterised (Pawlik 1990). Polyunsaturated fatty acids, located in the burrows of adult worms, have been described to induce gregarious settlement in trochophore larvae of the polychaete Phragmatopoma californica (Pawlik 1988, 1990). Contrary evidence was presented by Jensen \& Morse (1991), who suggested that the natural inducer might not be a fatty acid, but more likely a dihydroxyphenylalanine (DOPA) derived compound. Capitella capitata larvae can be induced to settle and metamorphose upon exposure to juvenile hormones (JHs), of which the $\mathrm{JH}$ analogue methyl farnesoate is the most effective.

A number of polyunsaturated fatty acids have also proved effective (Biggers \& Laufer 1992). In a recent review Rodríguez et al. (1993) describe a number of compounds, most of them involved in mechanisms of signal transduction as 'artificial inducers', that may not act directly on the signal receptor of the receiving larvae. Chemical cues associated with a suitable settlement substratum are often known to mimic the action of neurotransmitters, indicating the importance of neuronal receptors during larval settlement processes. Such compounds include GABA ( $\gamma$-aminobutyric acid), a product of glutamic acid decarboxylation which increases membrane permeability to chloride ions, thus inducing polarisation of post synaptic membranes. GABA has been isolated from tissues of encrusting red algae and identified by Morse et al. (1979) to induce settlement in abalone Haliothes rufescens. This activity is linked to the presence of small 'peptide associated' inducer molecules which greatly increase the sensitivity of the larva (Morse \& Morse 1984a, b). These cues were described to be lysine and other related amino acids by Morse (1991). Although GABA has also been shown to be active in a number of other molluscan species (Morse et al. 1984, Pawlik 1990), no effect was observed by a number of authors using different phyla (Hadfield 1984, Coon et al. 1985, Pawlik 1990 ) including abalone. Recent investigations by Slattery (1992), for example, indicate the importance of chemical cues from conspecific mucus containing some unknown inducers during abalone settlement.

Tyrosine derivatives such as L-DOPA and the catecholamines dopamine, adrenaline and noradrenaline have been shown to induce settlement in bivalves. Tyrosine induces settlement in larvae of Crassostrea virginica and Mytilus edulis (Pawlik 1990), L-DOPA in Crassostrea gigas (Bonar et al. 1985) and dopamine in larvae of the gastropod Ilyanassa obsoleta (Levantine \& Bonar 1986) and the echinoid Dendraster excentricus (Burke 1983). 2,6-di-tert-butyl-4-methylphenol (DBMP), commonly known as butylated hydroxytoluene, has been found to induce metamorphosis in Phragmatopoma californica (Pawlik 1990) Choline, a precursor of the neurotransmitter acetylcholine induces metamorphosis in the nudibranchs Phestilla sibogae (Hadfield 1984) and Adalaria proxima (Todd et al. 1991). The mechanism involved is still uncertain but it has been suggested that choline acts directly on the central nervous system, e.g. by the stimulation of catecholamine neurotransmitters (Pawlik 1990). Similarly, the tryptophane derivative neurotransmitter Serotonin (5-hydroxytryptamine) induces metamorphosis in Ilyanassa obsoleta (Levantine \& Bonar 1986). Lastly, small peptides have received much recent attention as potential chemical inducers of settlement. Larvae of Balanus amphitrite (Tegtmeyer \& Rittschoff 1989), C. virginica (Zimmer-Faust \& Tamburi 1994), A. proxima (Lambert 1995, Lambert et al. 1997), Phestilla sibogae (Hadfield \& Pennington 1990) and Hydractinia echinata (Leitz et al. 1994) respond to waterborne peptides that are smaller than 1000 Da molecular weight, but none of these molecules has yet been fully characterised.

\section{Arenicola marina}

Arenicola marina, the lugworm, is a common polychaete in sand flats in Northern Europe, where it usually reproduces in autumn or early winter (Howie 1959). The reproductive biology has been reviewed most recently by Howie (1984). Reproduction of a population is often highly synchronised and occurs during periods of low water during spring tides (Howie 1959. Duncan 1960). Spawning males ejaculate sperm onto the surface of the sediment, whereas female lugworms shed eggs within the burrow. The incoming tide, in conjunction with vigorous pumping activity of the females, ensures transport of spermatozoa into the burrow, where fertilisation takes place. Newly hatched 
larvae of $A$. marina usually have up to 3 chaetigerous segments. Although these larvae are often able to swim with ciliary movements (Newell 1948), the larval development includes only a very short or in some cases no pelagic stage so that larvae are usually not detectable in plankton hauls (Thorson 1950). Juveniles and adults of $A$. marina are commonly found heterogeneously distributed over tidal flats, with juveniles of ten seen to occur in higher and sheltered areas, separated from adults in the population. Migration of juveniles has been described to occur during the night (Farke \& Berghuis 1979), and, once the juveniles have migrated to a suitable area of sediment, the tendency to swim decreases, mucus is secreted and the juveniles adhere to the substratum and then subsequently build a tube (Farke et al. 1979). In this paper we assess the settlement inducing and settlement selection potential of natural sediments that have been exposed to various 'natural cues' from either conspecifics or infaunal species, phytoplankton and cryptomonad extracts and a number of synthetic organic molecules. The objective of these studies is to investigate the relative importance of positive and negative cues on sediment selection by juvenile $A$. marina.

\section{MATERIALS AND METHODS}

Collection and maintenance of specimens. Gravid Arenicola marina were collected during low tide from East Sands (St. Andrews) and Dunbar, SE Scotland, during the week immediately prior to the natural spawning season which occurs in October (East Sands) and early December (Dunbar). Lugworms were transported back to the laboratory, sexed by light microscopical observation of gametes taken from the coelomic cavity, and placed individually in plastic containers filled with approximately $150 \mathrm{ml}$ sea water Specimens were maintained for periods of up to $2 \mathrm{wk}$ in the laboratory at constant $10^{\circ} \mathrm{C}$ under ambient photoperiod conditions. In order to achieve fertilisation under controlled laboratory conditions both sexual partners were injected with spawning hormones to induce release of gametes as described by Pacey \& Bentley (1992). Males $(n=10)$ were injected with $13 \mu \mathrm{g}$ $\mathrm{g}^{-1}$ body weight of the male spawning hormone 8,11,14-eicosatrienoic acid. 8,11,14-eicosatrienoic acid was obtained from Sigma Chemical Co. and $1 \times 10^{-2} \mathrm{M}$ stock solutions prepared in HPLC-grade methanol. For use, aliquots of these stock solutions were diluted 100 fold to give a final concentration of $1 \times 10^{-4} \mathrm{M}$. Females were injected with prostomium homogenate (1 prostomium per female), also as described by Pacey \& Bentley (1992). This procedure resulted in the release of gametes in males after $60 \mathrm{~min}$ and females after 4 to
6 h. Gametes were mixed at a sperm:egg ratio of $10^{4}: 1$ and fertilisation was allowed to occur. The remaining sperm were then removed by decantation and the fertilised eggs were washed twice with TFSW [triple filtered (at $0.22 \mu \mathrm{m})$ sea water $(30 \%)$ )]. Developing larvae were separated into new glass dishes $(500 \mathrm{ml})$ with fresh TFSW after $24 \mathrm{~h}$, sea water was changed daily by decanting through a $200 \mu \mathrm{m}$ mesh, and the cultures were fed 3 times a week with Rhodomonas sp. Some of the larvae were cultured separately without feeding. Cultures were maintained under ambient photoperiod conditions. We have used the cryptomonad Rhodomonas sp. previously for rearing of a number of marine invertebrate larvae and it was therefore chosen as a potential feeding stimulant.

Bioassay procedures. Settlement experiments were carried out with 3 -setiger nectochaete larvae (most of them still showing some swimming behaviour), 1 mo old 5-setiger stages, and 3 mo old juveniles (up to $1 \mathrm{~cm}$ ). For bioassay, 2 different methods, each adapted to a particular stage of development, were employed. Three-setiger larvae were assayed by adding 40 swimming larvae ( 3 replicates per treatment) to different substrata/cues in a petri dish $(15 \mathrm{~cm})$ filled with $200 \mathrm{ml}$ TFSW. For each set of experiments controls were set up using sterilised sand (collected from East Sands). Larvae were allowed $8 \mathrm{~h}$ to settle. As these larvae are very difficult to detect when settled on sand, the settlement rate was determined initially by recording the remaining number of swimming larvae. Five setiger stages and juveniles were bioassayed in a $9 \mathrm{~cm}$ petri dish with 2 vertical dividers ( $7 \mathrm{~mm}$ high) giving 4 equal compartments. For assays each dish was assembled with 2 substrata under investigation in opposing compartments (2 $\mathrm{mm}$ high), 15 larvae/juveniles were placed randomly in the dish which was filled with TFSW. All assays were maintained in a temperature and daylight controlled incubator under winter conditions $\left(6^{\circ} \mathrm{C}, 6 \mathrm{~h}\right.$ of daylight $)$ for $24 \mathrm{~h}$. As juvenile Arenicola marina are very difficult to identify against a sediment background, specimens were placed for $2 \mathrm{~h}$ in a non-toxic food dye (Brilliant Blue FC) to improve visibility. After $24 \mathrm{~h}$ sediment and TFSW were removed from each compartment and transferred to a counting dish under a binocular microscope. The number of settled juveniles was confirmed by counting stained individuals in the sediment and data were analyzed using chi-squared tests.

Prior to examination of chemically enriched sediments, particle size preference was examined using baked sieved sand $(106,250$ and $500 \mu \mathrm{m}$ ) collected from natural juvenile settlement sites at East Sands. Sediment types under investigation as possible settlement cues are shown in Table 1. They include natural sediment and sand enriched with food as well as with 
Table 1. Induction of settlement in juvenile Arenicola marina: substances/substrata under investigation

\begin{tabular}{|c|c|c|}
\hline Settlement cue & Dose & Control \\
\hline \multicolumn{3}{|l|}{ Amino acids/tripeptides } \\
\hline Tyrosine & $100 \mathrm{mg} .10 \mathrm{mg}$ & Sterile sediment \\
\hline Alanine & $100 \mathrm{mg}$ & Sterile sediment \\
\hline Glycine & $100 \mathrm{mg}, 10 \mathrm{mg}, 1 \mathrm{mg}$ & Sterile sediment \\
\hline Arg-Gly-Asp & $100 \mathrm{mg}, 10 \mathrm{mg} .1 \mathrm{mg}$ & Sterile sediment \\
\hline Gly-Gly-Arg & $100 \mathrm{mg}, 10 \mathrm{mg}, 1 \mathrm{mg}$ & Sterile sediment \\
\hline \multicolumn{3}{|l|}{ Neurotransmitters } \\
\hline Dopamine & $100 \mathrm{mg}$ & Sterile sediment \\
\hline Serotonine & $100 \mathrm{mg}$ & Sterile sediment \\
\hline$\gamma$-aminobutyric acid (GABA) & $100 \mathrm{mg}$ & Sterile sediment \\
\hline \multicolumn{3}{|l|}{ Fatty acids } \\
\hline $8,11,14$-eicosatrienoic acid & $100 \mathrm{mg}, 10 \mathrm{mg}, 1 \mathrm{mg}, 0.1 \mathrm{mg}, 0.01 \mathrm{mg}$ & Sterile sediment \\
\hline Arachidonic acid & $100 \mathrm{mg}, 10 \mathrm{mg}, 1 \mathrm{mg}$ & Sterile sediment \\
\hline 11,14,17-eicosatrienoic acid & $100 \mathrm{mg}, 10 \mathrm{mg}, 1 \mathrm{mg}$ & Sterile sedimen \\
\hline \multicolumn{3}{|l|}{ Natural sediments } \\
\hline Juvenile $A$. marina sediment & & Sterile sediment \\
\hline Adult $A$. marina sediment & & Sterile sediment \\
\hline Nephtys hombergii sediment & & Sterile sediment \\
\hline \multicolumn{3}{|l|}{ Feeding stimulants } \\
\hline Liquifry Marine fish food & $1 \mathrm{ml}$ & Sterile sediment \\
\hline Tetra-Marine fish food & $1 \mathrm{ml}$ & Sterile sediment \\
\hline Rhodomonas sp. enriched sand & $10^{6}$ cells $\mathrm{ml}^{-1}$ & Sterile sediment \\
\hline \multicolumn{3}{|l|}{ Negative cues } \\
\hline 3,5-dibromo-4-hydroxybenzoic acid & $10 \mathrm{mg}, 1 \mathrm{mg}, 0.1 \mathrm{mg}, 0.01 \mathrm{mg}$ & Sterile sedıment \\
\hline 1,4-dibromobenzene & $0.1 \mathrm{mg}$ & Sterile sediment \\
\hline 2,6-dibromophenol & $10 \mathrm{mg}, 1 \mathrm{mg}, 0.1 \mathrm{mg}$ & Sterile sediment \\
\hline 3,5-dibromo-4-hydroxybenzoic acid & $10 \mathrm{mg}, 1 \mathrm{mg}, 0.1 \mathrm{mg}$ & N. hombergii sand \\
\hline A. marina 'stress' excretion & Excretion from 1 adult & N. hombergii sand \\
\hline N. hombergii 'stress' excretion & Excretion from 1 individual & N. hombergii sand \\
\hline
\end{tabular}

synthetic chemicals. Synthetic chemicals were obtained from Sigma Chemical Co. and stock solutions $\left(1 \mathrm{mg} \mathrm{ml^{-1 }}\right.$ ) prepared in HPLC-grade ethanol. For use in bioassays, stock solutions were diluted with TFSW and added to $1 \mathrm{~g}$ of sterilized sediment (in $1 \mathrm{ml}$ TFSW); the sample was then allowed to settle for $30 \mathrm{~min}$ and finally TFSW was added to give a final volume of $10 \mathrm{ml}$.

\section{RESULTS}

As shown in Fig. 1a juvenile Arenicola marina have a particle size preference in the sediment that they select for settlement. Fine $(106 \mu \mathrm{m})$ sediments were preferred over coarse (over $500 \mu \mathrm{m})$ sediments $\left(\chi^{2}=\right.$ 16.4 significant with $1 \mathrm{df})$, and medium $(250 \mu \mathrm{m})$ particle size sediments were preferred over fine $\left(\chi^{2}=5.73\right)$ and coarse $\left(\chi^{2}=19.1\right)$ ones. Since assays were carried out in paired 'choice chamber experiments', a $\chi^{2}$ test of observed versus expected is appropriate. Adult lugworm populated sediment had a slight negative effect (Fig. $1 \mathrm{~b}, \chi^{2}=16.93$ ) and was chosen by fewer juveniles than sterile sand, functioning as control, whereas juve- nile sand was highly attractive $\left(\chi^{2}=8.0\right.$ for juvenile vs sterile sand, significant with $1 \mathrm{df}$ ). Nephtys hombergii is often found in the same habitat as lugworms and sediment collected from a $N$. hombergii settlement site at East Sands was therefore included as potentially attractive (Fig. 1b). This sediment proved very attractive to juvenile lugworms and was even preferred over sand from juvenile sites $\left(\chi^{2}=8.4\right.$ significant with $\left.1 \mathrm{df}\right)$. This positive response occurred regardless of whether juvenile lugworms or 5 d old larvae were assayed. Fig. 1b, c shows that there is no significant difference in the response to conspecific signals between young, free swimming larvae and juveniles of up to 6 mo of age.

Sediments containing fatty acids, particularly $8,11,14$-eicosatrienoic acid $\left(\chi^{2}=5.73\right.$, significant at $1 \mathrm{df}$, at $3 \times 10^{-6} \mathrm{M}$ ), and also amino acids, especially glycine both singly $\left(\chi^{2}=9.47\right.$, significant at $1 \mathrm{df}$, at $\left.3 \times 10^{-5} \mathrm{M}\right)$ and in tripeptide form $\left(\chi^{2}=8.40\right.$, significant at $1 \mathrm{df}$, at $3 \times 10^{-5} \mathrm{M}$ ), were attractive for juvenile lugworms to settle when assayed versus sterile sand (Fig. 2). Marine food, e.g. Tetra-Marine and Liquifry Marine, enriched sediments were also as attractive $\left(\chi^{2}=8.41, \chi^{2}=6.42\right.$, significant at $1 \mathrm{df}$, at $1 \%$ solution) as the fatty acids, 
indicating that lugworms detect organically enriched sites by the availability of 'food sources'.

Negative settlement cues characterising unsuitable settlement sites have been investigated very rarely, but may be of immense importance in the detection and examination of possible settlement sites for larvae. Aromatic compounds are excreted by some benthic invertebrates as chemical defense substances, e.g. by terrebellid polychaetes (Woodin et al. 1993). As shown in Fig. 3a all 3 brominated compounds lead to a rejection of the medium particle size sediment by the larvae; 3,5-dibromo-4-hydroxybenzaic acid induced the most negative effects, with larvae avoiding this compartment and choosing the sterile sand $\left(\chi^{2}=\right.$ 22.8, significant at $1 \mathrm{df}$, at $\left.3 \times 10^{-7} \mathrm{M}\right) .2,6$-dibromophenol $\left(\chi^{2}=20.1\right.$, significant at $1 \mathrm{df}$, at $3 \times$ $\left.10^{-6} \mathrm{M}\right)$ and 1,4 dibromobenzene $\left(\chi^{2}=20.1\right.$, significant at $1 \mathrm{df}$, at $3 \times 10^{-6} \mathrm{M}$ ) induced similar negative reactions but significantly higher concentrations were needed.

We also used sediment from a Nephtys hombergii settlement site, which was attractive to juvenile lugworms, and treated this with a number of potentially negative cues in order to investigate the relative importance of both types of cues. Addition of $10^{-6}$ M 3,5-dibromo-4-hydroxybcnzoic acid to sediment resulted in a complete rejection of previously very attractive sediment (Fig. $3 \mathrm{~b} ; \chi^{2}=19.1$, significant at $1 \mathrm{df}$, at $3 \times$ $10^{5} \mathrm{M}$ ). If stressed mechanically, adult Arenicola marina release a yellow mucoid fluid, which turns brownish after a short time. Addition of this secretion to previously attractive samples such as $N$. hombergii settlement sand resulted in an avoidance of the treated sediment (Fig. $3 b ; \chi^{2}=$ 22.2, significant at $1 \mathrm{df}$ ). $N$. hombergii, when stressed, also excretes a body fluid characterised by a strong smell reminiscent of male cat odour, hence their common name 'cat-worm'. Addition of this excretion to sediment samples resulted in rejection by the juvenile lugworms (Fig. $3 b_{;} \chi^{2}=$ 12.8, significant at $1 \mathrm{df}$ ).

\section{DISCUSSION}

In contrast to many marine benthic invertebrates that settle and metamorphose in response to a specific inducer (Jensen \& Morse 1991), the present results indicate that Arenicola marina juveniles can respond to a wide range of organic compounds and physical cues. These include both positive (attraction) and negative (avoidance) reactions, and the overall response of $A$.
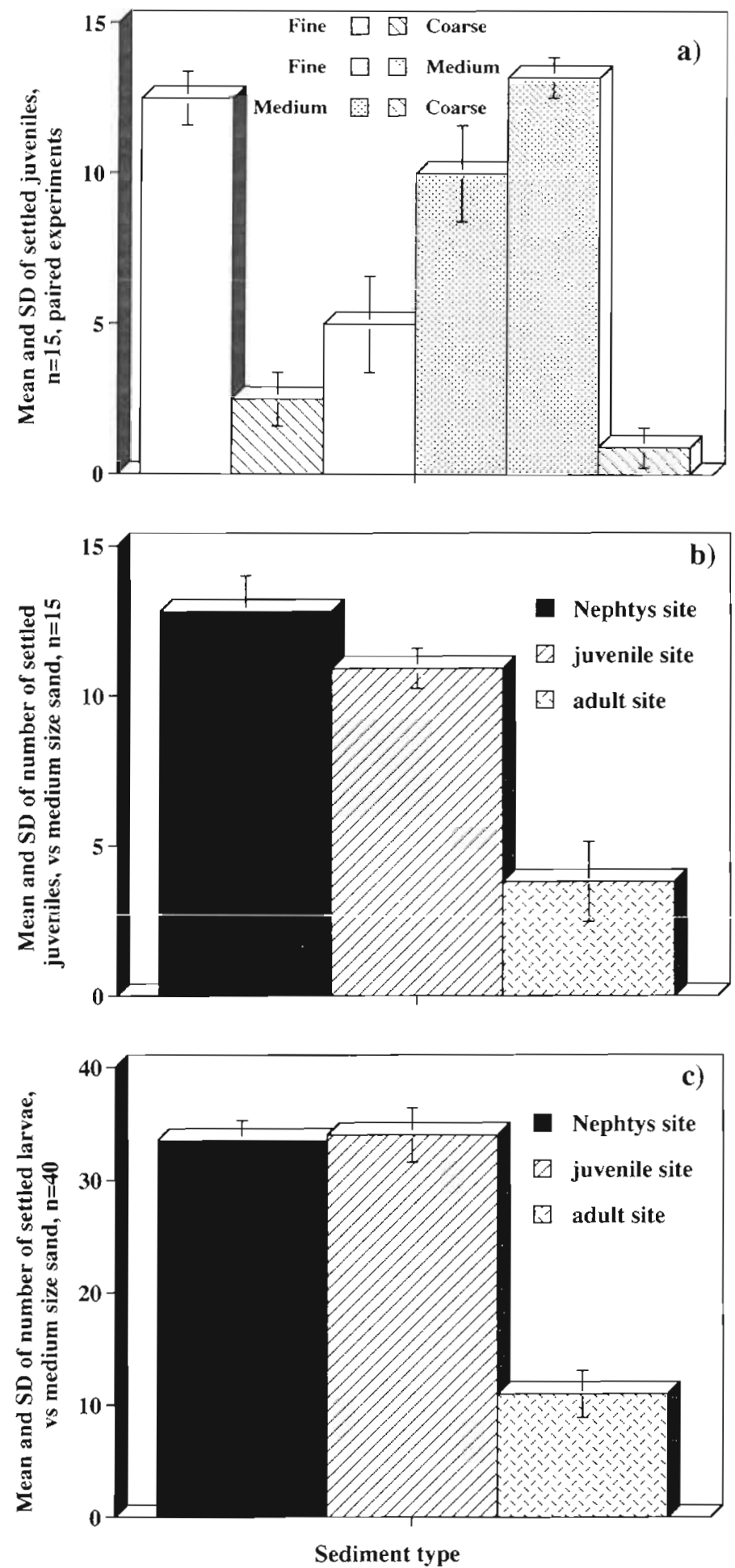

Fig. 1. Arenicola marina. (a) Sediment choice (particle size) of juvenile worms upon exposure to 'natural' sediments collected at East Sands, St. Andrews, Scotland, in paired experiments, $n=15,3$ replicates. (b) Settlement of juvenile worms upon exposure to natural sediments vs sterile sand (medium particle size of $250 \mu \mathrm{m}$ ), $n=15,3$ replicates. (c) Settlement of $7 \mathrm{~d}$ old larvae upon exposure to natural sediments vs sterile sand (medium particle size of $250 \mu \mathrm{m}$ ), $\mathrm{n}=40$, 3 replicates 


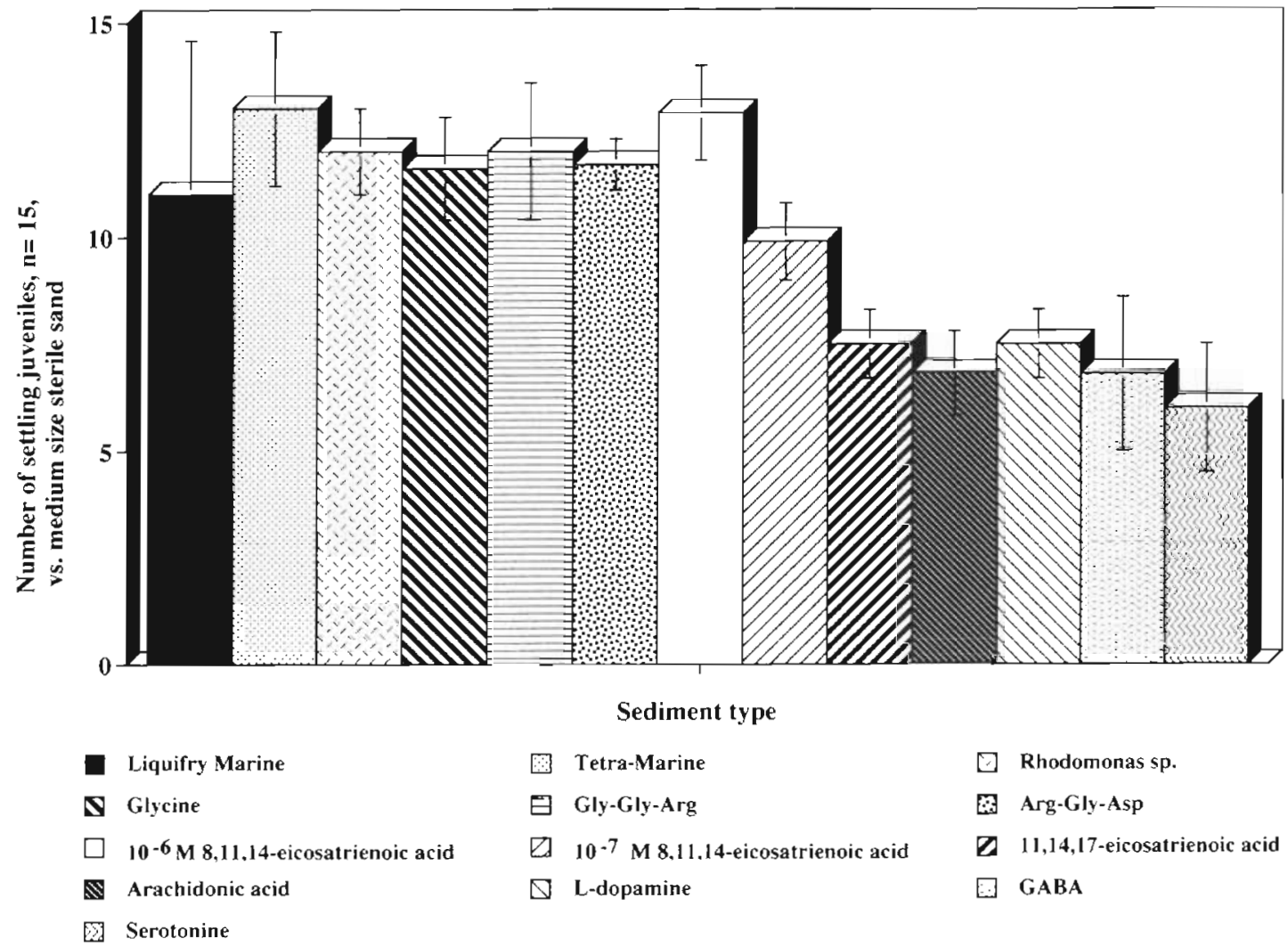

Fig. 2. Arenicola marina. Sediment choice of juvenile worms upon exposure to synthetic 'positive' cues, $\mathrm{n}=15,3$ replicates, $10^{-5} \mathrm{M}$. except for $8,11,14$-eicosatrienoic acid, where $10^{-6}$ and $10^{-7} \mathrm{M}$ was used. All data represent paired experiments vs sterile sand (medium particle size of $250 \mu \mathrm{m}$ ) i data pooled

marina juveniles is likely to be a combination of these cues. Juvenile $A$. marina show a clear particle size preference when searching for suitable settlement sites. Sand with a medium particle size (of $\sim 250 \mu \mathrm{m}$ ) was preferred over fine and coarse sand (see Fig. 1a). In the field, aggregations of juvenile lugworms are often found in more sheltered, shoreward regions, which usually have sediments with a medium particle size (Woodin 1991). Fig. 1b shows that the spatial separation of juvenile and adult lugworms often found in the field (Newell 1948) might be based on a combination of aggregation of juveniles and avoidance of adult sites. There is clearly an attraction of juvenile lugworms to conspecifics in a gregarious type of response and a negative effect of adult populated sediment. The aggregation of juveniles has been described as advantageous, with higher survival rate of juveniles in areas not dominated by adults (Farke et al. 1979). Thus, our data also indicate that these reactions do not depend on the physical presence of such conspecifics but on the 'odour' of chemicals emitted by these individuals. To date, the chemical structure of both the negative cues from adults and the positive cues from other juve- niles are unknown but future investigations will focus on the structural evaluation of these signal molecules.

Interestingly, our results demonstrate that there is no significant difference in the response to conspecific signals between the very young, free swimming larvae and juveniles of up to 6 mo of age (Fig. 1b, c). The desperate larvae hypothesis (Knight-Jones 1953) does not hold for Arenicola marina. Similar to experiments by Toonen \& Pawlik (1994) using Hydroides dianthus, lugworm larvae and juveniles were not fed during the experimental period but no differences, especially no increase in the level of settlement response, over time/age were detectable.

Sediment samples taken from an area dominated by Nephtys hombergii and Nephtys caeca proved to be highly attractive for juvenile lugworms, indicating the complexity of settlement response in Arenicola marina. It is possible that nitrogenous compounds like ammonia are present in these sediments, indicating a high metabolic activity; such compounds have been demonstrated to induce searching behaviour in Crassostrea gigas by Coon et al. (1990). N. hombergii dominated sediments are often rich in organic material and we 
therefore investigated the theory that juvenile lugworms choose 'organically enriched' sediments as preferred settlement sites. Enrichment of sediment with marine food significantly increased settlement, as shown in Fig. 2, and elicited settlement rates similar to the gregarious response from juvenile lugworms.

Films of diatoms, bacteria, algae and cyanobacteria have been described to induce settlement in a wide range of benthic invertebrates (see Rodríguez et al. 1993 for review) and our data confirm the attractiveness of biofilms in the lugworm. There are clear preferences for settlement on areas enriched with a film of cryptomonad Rhodomonas sp. It is not known yet if such a response is based on the detection of extracellular compounds and soluble compounds released from the microorganisms, such as has been described for various marine invertebrates (Bonar et al 1990, Coon et al. 1990), but this will form part of our future investigations. Nevertheless, this attractiveness reinforces the hypothesis that settlement in juvenile lugworms can be induced by organically enriched and therefore potentially favourable settlement sites.

A great variety of synthetic chemicals have been postulated as potential larval settlement inducers in marine invertebrates (see Rodríguez et al. 1993 for review) and we therefore also investigated the effects of a number of these substances. From the results, it can be seen that fatty acids, particularly 8,11,14eicosatrienoic acid, and also amino acids, especially glycine both singly and in tripeptide form, are attractive and induce juvenile lugworms to settle. The role of fatty acids in marine invertebrates is a complex one, with these acids performing a number of functions in the endocrine system. Fatty acids have been demonstrated to modulate potassium channels (Ordway et al. 1989), activate guanylate cyclase, inhibit $\mathrm{Na}^{+} / \mathrm{K}^{+}$-ATPase (Chan et al. 1983) and protein kinase (Speizer et al. 1991). Such activities of fatty acids are important considering that settlement is an event mediated by neuro-physiological means. The most potent inducer in the experiments was $8,11,14$-eicosatrienoic acid, a $\mathrm{C}_{20} \omega-3$ fatty acid derived from $\gamma$-linolenic acid. This fatty acid has been recently described as a spawning hormone in Arenicola marina, inducing the release of gametes in males as well as the activation and maturation of the spermatozoa (Bentley \& Pacey 1992, Pacey \& Bentley 1992, Bentley \& Hardege 1996). Biggers \&
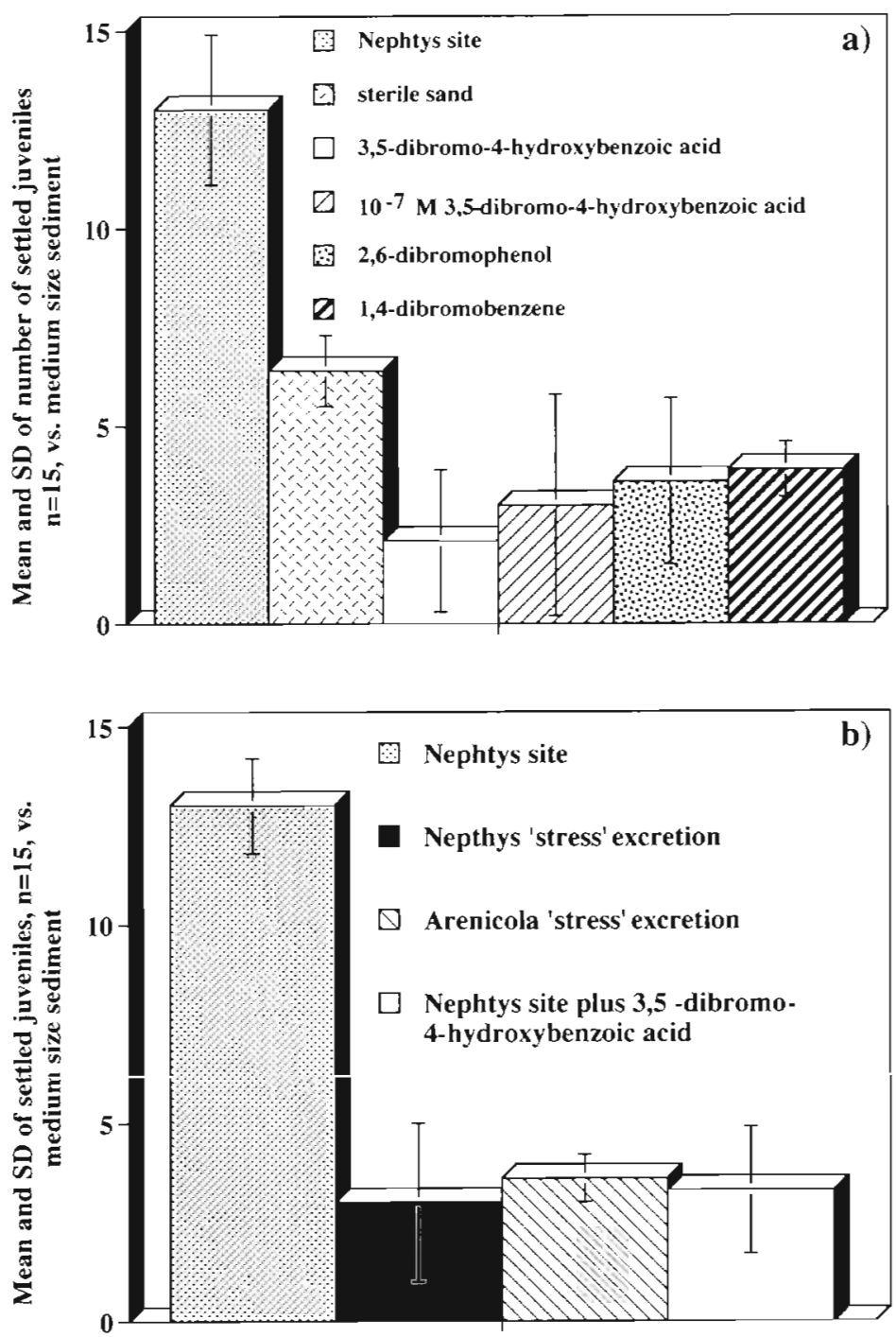

Sediment type

Fig. 3. Arenicola marina. Sediment choice of juvenile worms upon exposure to (a) synthetic brominated compounds added to potentially 'attractive' sediment (medium particle size of $250 \mu \mathrm{m}$ ) and (b) 'negative' cues from natural sediments, $n=15,3$ replicates, $10^{-6} \mathrm{M}$ except for $8,11,14$ eicosatrienoic acid, where $10^{-7}$ was used as well. All experiments represent paired vs sterile sand (medium particle size of $250 \mu \mathrm{m}$ ), data pooled

Laufer (1992) induced settlement and metamorphosis in the polychaete Capitella capitata by exposure to fatty acid derivatives such as methyl-farnesoate and a number of $\mathrm{C}_{20}$ fatty acids, one of them being the $\omega-3$ fatty acid 5,11,18-eicosatrienoic acid, an isomer of the A. marina sperm maturation factor in our experiments.

Many tyrosine derivatives, such as dopamine in the echinoid Dendraster excentricus (Burke 1983), have been shown to act as inducers for larval settlement (Pawlik 1990). Dopamine as well as the other neurotransmitters serotonin and GABA failed to induce set- 
tlement in the Iugworm (Fig 2). It has been suggested that tyrosine derivatives are absorbed by juveniles and chemically transformed to dopamine, which then acts on dopaminergic receptors. Catecholamines seem to activate an endogenous sequence of metamorphic events (Bonar et al. 1985, Coon et al. 1985, Pawlik 1990). It is likely, however, that there is more than one pathway involved in the transduction of sediment cues. It is possible that dopamine and other tyrosine derivatives are involved in the settlement process in Arenicola marina through one or more of these pathways, but in our experiments they did not induce effective settlement responses when added to sterile sediment.

Negative settlement cues characterising unsuitable settlement sites have been investigated very rarely to date, but may be of immense importance for larvae in detecting and examining possible settlement sites. In a series of experiments Woodin (1991) and Woodin et al. $(1993,1995)$ showed that settlement of Nereis vexillosa and the lugworm Arenicola cristata is inhibited by the odour released by terebellid polychaetes, which is characterised by brominated aromatics. Aromatic compounds are in general highly hydrophobic, noxious or even toxic and are excreted by some benthic invertebrates as chemical defense substances. In our experiments the addition of 3,5-dibromo-4-hydroxybenzoic acid to sediment resulted in a complete rejection of this sediment as a settlement site. This occurred even if previously attractive sediment from a $N$. hombergii settlement site was used, suggesting that negative cues can override the attractive character of the sample (Fig. 3).

Sediment from settlement sites of adult Arenicola marina not only proved to be unattractive for juveniles, but was actively rejected when the adults were stressed (exposure to strong light or by mechanical disturbance). In such circumstances adult individuals released a yellow mucoid fluid. Addition of this secretion to previously attractive samples, such as Nephtys hombergii settlement sand, resulted in the avoidance of the treated sediment (Fig. 3). N. hombergii, also known as the catworm, also excretes a body fluid when stressed mechanically, or when exposed to strong light or noxious chemicals. This excretion is characterised by a strong smell, the 'cat smell'. Addition of this excretion to sediment samples again resulted in a rejection of the treated sand by the juvenile lugworms (Fig. 3). Both cases demonstrate that negative chemical cues leading to the avoidance of certain areas are of importance for the settlement choice of lugworms and future investigation will also focus on the characterisation of the cues involved in this behaviour.

Overall, settlement in Arenicola marina is quite unspecific, with a response to a number of different environmental cues. There is a preference for organi- cally enriched substrata of a particular particle size, with gregarious settlement of juveniles avoiding areas where adult conspecifics settle. This behaviour is significantly different to that of many marine invertebrates, the settlement cues of which are often very highly specific (see Rodriguez et al. 1993 for review). To date, our knowledge on the settlement of the lugworm and polychaetes in general is still far from complete but current results may represent a good model to study the complex variety of cues involved.

Acknowledgements. We thank M. Bayer and G. Watson for their help in collecting the specimens and J. Duck for her assistance with the lugworm culture. The authors are grateful for the support of grants GR3/8628 and GR3/10521 to M.G.B. and J.D.H. from the Natural Environment Research Council, UK.

\section{LITERATURE CITED}

Bentley MG, Hardege JD (1996) The role of a fatty acid hormone in reproduction of the polychaete Arenicola marina (L.). Int J Invertebr Reprod 30:159-165

Bentley MG. Pacey AA (1992) Physiological and environmental control of reproduction in polychaetes. Oceanogr Mar Biol Annu Rev 30:443-481

Biggers WJ, Laufer H (1992) Chemical induction of settlement and metamorphosis of Capitella capitata sp. (Polychaeta) larvae by juvenile hormone activity compounds. Int $\mathrm{J}$ Invertebr Reprod 22:39-46

Bonar DB, Coon SJ, Walch M, Weiner RM, Fitt W (1990) Control of oyster settlement and metamorphosis by endogenous and exogenous cues. Bull Mar Sci 164:484-498

Bonar DB, Coon SL, Weiner RM, Colwell RR (1985) Induction of oyster metamorphosis by bacterial products and biogenic amines. Bull Mar Sci 37:763 (abstract)

Burke RD (1983) Neural control of metamorphosis in Dendraster excentricus. Biol Bull (Woods Hole) 164:176-188

Chan PH, Fishman RA, Chen S, Chew S (1983) Effects of temperature on arachidonic acid induced cellular edema and membrane pertubation in rat brain cortical slices. J Neurochem 41:1550-1557

Chia FS, Koss R (1978) Development and metamorphosis of the planktonic larvae of Rostanga pulcha (Mollusca, Nudibranchia). Mar Biol 46:109-119

Chia FS, Rice ME (1978) Settlement and metamorphosis of marine invertebrate larvae. Elsevier, New York

Coon SL, Bonar DB, Weiner RM (1985) Induction of settlement and metamorphosis of the Pacific oyster Crassostrea gigas (Thunberg) by L-Dopa and catecholamines. J Exp Mar Biol Ecol 94:211-221.

Coon SL, Fitt WK, Bonar DB (1990) Competence and delay of metamorphosis in the Pacific oyster Crassostrea gigas. Mar Biol 106:379-387

Crisp DJ (1967) Chemical factors inducing settlement in Crassostera virginica (Gmelin). J Anim Ecol 36:329-335

Crisp DJ, Ritz DA (1973) Response of cirriped larvae to light: I. Experiments with white light. Mar Biol 23:327-335

Duncan A (1960) The spawning of Arenicola marina (L.) in the British Isles. Proc Zool Soc Lond 134:137-156

Farke H, Berghuis EM (1979) Distribution of juvenile and adult Arenicola marina on a tidal mud flat and the importance of nearshore areas for recruitment. Neth J Sea Res $13: 512-528$ 
Farke H, De Wilde PAW, Berghuis EM (1979) Spawning, larval development and migration of Arenicola marina under field conditions in the western Wadden Sea. Neth J Sea Res 13:354-361

Hadfield MG (1984) Settlement requirement of molluscan larvae: new data on chemical and genetic roles. Aquaculture 39:283-293

Hadfield MG, Pennington JT (1990) Nature of the metamorphic signal and its internal transduction in larvae of the nudibranch Phestilla sibogae. Bull Mar Sci 63:329-337

Howie DID (1959) The spawning of Arenicola marina L. 1. The breeding season. J Mar Biol Assoc UK 38:395-406

Howie DID (1984) The reproductive biology of the lugworm Arenicola marina (L.). In: Fischer A, Pfannenstiel HD (eds) Polychaete reproduction. Fortschr Zool 29. G Fischer Verlag, Stuttgart, p 247-263

Jensen RA, Morse DE (1984) lntraspecific facilitation of larval recruitments: gregarious settlement of the polychaete Phragmatopoma californica (Fewkes). J Exp Mar Biol Ecol 83:107-126

Jensen RA, Morse DE (1991) Chemically induced metamorphosis of polychaete larvae in both the laboratory and ocean environment. J Chem Ecol 16:911-930

Knight-Jones EWJ (1953) Laboratory experiments on gregariousness during settling in Balanus balanoides and other barnacles. J Mar Biol Assoc UK 32:337-345

Lambert WJ, Todd CD (1995) Evidence for a water-borne cue inducing metamorphosis in the dorid nudibranch mollusc Adalaria proxima (Gastropoda, Nudibranchia). Mar Biol 120:265-271

Lambert WJ, Todd CD, Hardege JD (1997) Partial purification and biological activity of a metamorphic inducer of larvae of the dorid nudibranch Adalaria proxima. Invertebr Biol $116: 71-81$

Leitz T, Beck HM, Stephan WD, Lehmann L, De Petrocellis, DiMarco V (1994) Possible involvement of arachidonic acid and eicosanoids in metamorphic events in Hydractinia echinata. J Exp Zool 269:422-431

Levantine PL, Bonar DB (1986) Metamorphosis of llyanassa obsoleta: natural and artificial inducers. Am Zool 26:14A

Morse ANC (1991) How do planktonic larvae know where to settle? Am Scient 79:154-167

Morse ANC, Froyd CA, Morse DE (1984) Molecules from cyanobacteria and red algae that induce larval settlement and metamorphosis in the mollusc Haliothis rufescens. Mar Biol 81:293-298

Morse ANC. Hooker N, Duncan H, Jensen L (1979) Gammaaminobutyric acid, a neurotransmitter, induces planktonic abalone larvae to settle and begin metamorphosis. Science 204:407-410

Morse ANC, Morse DE (1984a) Recruitment and metamorphosis of Haliotis larvae induced by molecules uniquely available at the surface of crustose red algae. J Exp Mar Biol Ecol 75:191-215

Morse ANC, Morse DE (1984b) GABA-mimetic molecules from Porphyra (Rhodophytaj induce metamorphosis of Haliothes (Gastropoda) larvae. Hydrobiologia 116:155-158

Newell GE (1948) A contribution to our knowledge of the life history of Arenicola marina L. J Mar Biol Assoc UK 27 $554-580$

Ordway RW, Walsh RV, Singer JJ (1989) Arachidonic acid and other fatty acids directly activate potassium channels in smooth muscle cells. Science 244:1176-1178

Pacey AA, Bentley MG (1992) The fatty acid 8,11,14eicosatrienoic acid induces spawning in the male lugworm Arenicola marina. J Exp Biol 173:165-179

Pawlik JR (1986) Chemical induction of larval settlement and metamorphosis in the reef-building polychaete Phragmatopoma californica (Polychaeta: Sabelleridae). Mar Biol 91:59-68

Pawlik JR (1988) Larval settlement and metamorphosis of two gregarious polychaetes: Sabellaria alveolata compared with Phragmatopoma californica. J Mar Biol Assoc UK 68: 101-124

Pawlik JR (1990) Natural and artificial induction of metamorphosis of Phragmatopoma californica (Polychaeta: Sabelleridae) with a critical look at the effects of bioactive compounds on marine invertebrate larvae. Bull Mar Sci 46: $512-536$

Pawlik JR (1992) Chemical ecology of the settlement of benthic marine invertebrates. Oceanogr Mar Biol Annu Rev 30:273-335

Pawlik JR, Butman CA, Starczak V (1991) Hydrodynamic facilitation of gregarious settlement of a reef building tube worm. Science 251:421-424

Pearce CM, Scheibling RE (1990) Induction of metamorphosis in the green sea urchin Strongylocentrotus droebrachiensis (Mueller) by corraline red algae. Biol Bull (Woods Hole) $107: 363-369$

Pearce CM, Scheibling RE (1991) Effect of microalgae, microbial films and conspecifics on the induction of metamorphosis of the green sea urchin Strongylocentrotus droebrachiensis (Mueller). J Exp Mar Biol Ecol 147:147-162

Rodríguez SR, Ojeda FP, Inestrosa NC (1993) Settlement of benthic marine invertebrates. Mar Ecol Prog Ser 97:193-207

Slattery M (1992) Larval settlement and juvenile survival in the red abalone, Haliothes rufescens: an examination of inductive cues and subtrate selection. Aquaculture 102:143-153

Speizer LA, Watson ML, Brunton LL (1991) Differential effects of $\omega-3$ fish oils on protein kinase activities in vitro. Am.I Physiol 261:109-115

Stenneck RS (1982) A limpet coralline alga correlation: adaptation and selective pressure between a marine herbivore and its prey. Ecology 63:507-522

Svane I, Havenhand JN, Jorgensen A.J (1987) Effects of tissue extracts of adults on metamorphosis in Ascidia mentula (O.F. Mueller) and Ascidia scabra (O.F. Mueller). J Exp Mar Biol Ecol 110:171-181

Tegtmeyer K, Rittschoff D (1989) Synthetic peptide analogs to barnacle settlement pheromones. Peptides 9:1403-1406

Thorson G (1950) Reproductive and larval ecology of marine bottom invertebrates. Biol Rev 25:1-45

Todd CD (1979) The annual cycles of two species of Onchidoris (Opisthobranchia, Nudibranchia). In: Naylor E, Hartnoll RG (eds) Cyclic phenomena in marine plants and animals. Pergamon Press, Oxford, p 65-72

Todd CD, Bentley MG, Havenhand JN (1991) Larval metamorphosis of the opisthobranch mollusc Adalaria proxima (Gastropoda: Nudibranchia): the effects of choline and elevated potassium ion concentration. J Mar Biol Assoc UK 71:53-72

Toonen RJ, Pawlik JR (1994) Foundation of gregariousness. Nature 370:511-512

Woodin SA (1991) Recruitment of infauna: positive or negative cues? Am Zool 13:797-807

Woodin SA, Lindsay SM, Whethey DS (1995) Process-specific recruitment cues in marine sedimentary systems. Biol Bull (Woods Hole) 189:49-58

Woodin SA, Marinelli RL, Lincoln DE (1993) Allelochemical inhibition of recruitment in a sedimentary assemblage. J Chem Ecol 19:517-530

Zimmer-Faust RK, Tamburi MN (1994) Chemical identity and ecological implications of a waterborne larval settlement cue. Limnol Oceanogr 39:1075-1087 